\title{
SCHOOL COMMITTEE PERFORMANCE IN MINIMUM SERVICE STANDARD OF BASIC EDUCATION
}

\author{
Akhirin \\ Universitas Islam Nahdlatul Ulama Jepara, Jawa Tengah \\ Email :abihusni57@gmail.com \\ DOI: https://doi.org/10.37758/jat.v3i1.205 \\ \begin{tabular}{l|l|l} 
Received: Maret 2020 & Accepted: Juni 2020 & Published: Juni 2020
\end{tabular}

\begin{abstract}
:
This research is aimed at describing the implementation of Minimum Standard of Education (MSE) and performance of school committee in supervising the implementation of Minimum Standard of Education (MSE) at Junior High School in Jepara. This research is descriptive research with qualitative approach. The data collection was conducted through questionnaire, interview, documentation study, and observation. The data analysis used descriptive qualitative. The research result showed that the implementation of Minimum Standard of Education (MSE) had average good score at State of Junior High School and less than good in Private Junior High School. In the meantime, the supervisory duties of school committee to the implementation of MSE showed poor grades.
\end{abstract}

Key words : Implementation, Education Standard, Supervision

\begin{abstract}
Abstrak:
Penelitian ini bertujuan untuk mendeskripsikan pelaksanaan Standar Minimal Pendidikan (SPM) dan kinerja komite sekolah dalam mengawasi pelaksanaan Standar Minimal Pendidikan (SPM) di Sekolah Menengah Pertama Kabupaten Jepara. Penelitian ini berjenis deskriptif dengan menggunakan pendekatan kualitatif. Pengumpulan data dilakukan melalui angket, wawancara, studi dokumentasi dan observasi. Analisis data dilakukan secara deskriptif kualitatif. Hasil penelitian menunjukkan bahwa penerapan Standar Minimal Pendidikan (SPM) menunjukkan rerata nilai baik pada SMP Negeri dan kurang baik pada SMP Swasta, sedang tugas pengawasan komite sekolah terhadap penerapan SPM menunjukkan nilai kurang baik.
\end{abstract}

Kata Kunci : Penerapan, Standar Pendidikan, Pengawasan. 


\section{INTRODUCTION}

Education is co-responsibility of government, school and society as educative stakeholders. Indonesia government through Government Regulations (PP) and Decrees of the Minister of National Educations have sought to increase community participation in improving the quality of education by the establishment of Education Board and School Committee. The establishment of school committee is meant to integrate parents into education management of education units as mentioned in Minister of Education and Culture Regulation number 75 in 2016 about School Committee. ${ }^{1}$ Education governance is emerging as an important issue forschool effectiveness. ${ }^{2}$

The school committee is part of the school. A schoolwithout school committee will not be able to run well inachieving goals. ${ }^{3}$ The percentage of the function and committee implementation in Junior High School Jepara was showed by data; the role of school committee as advisor was $50 \%$; as promoter agent was $60 \%$; as controller was $45 \%$; and as mediator was $55 \%$. The percentage of understanding about the basic concept of school comprehension by school committee members at Junior High School in Jepara showed that 33\% members of school committee understood the concept, $51 \%$ of school committee members conducted their roles well, and only $42 \%$ of school committee members conducted their functions well (Akhirin, 2016).

The research about school committee and its empowerment has been conducted by researchers namely Supriyanto (2013), Ratnaningtyas and Setiyani (2017), Marayani and Nurkhimayanti (2014), Ninik (2017), Supa'at (2012), Herlina (2012), Pandoyo (2007), and Zulkifli (2015). The focus of the researches was dealing with the existence of school committee, the participation of school

\footnotetext{
${ }^{1}$ Depdiknas, "Peraturan Menteri Pendidikan Dan Kebudayaan Republik Indonesia Nomor 75.Tahun 2016 Tentang Komite Sekolah," Permendikbud Nomor 75 Tahun 2016, 2016, 1-11.

${ }^{2}$ Katherine Curry et al., "School Board Governance in Changing Times: A School's Transition to Policy Governance," Administrative Issues Journal: Education, Practice, and Research 8, no. 1 (2018): 117, doi:10.5929/2018.8.1.1.

${ }^{3}$ Abdul Halik et al., "Empowerment of School Committee in Improving Education Service Quality at Public Primary School in Parepare City," Universal Journal of Educational Research 7, no. 9 (2019): 1956-63, doi:10.13189/ujer.2019.070915.
}

42 | At-Tarbiyat : Jurnal Pendidikan Islam, Vol. 03 No. 01 (2020) : 41-53 
committee members toward the development of quality of education and school, the role of school committee in School-based management (SBM), and the roles of school committee in financial management, infrastructure as well as school finance supervisory commission. Other research on school committees was also conveyed more deeply by Herwan, Aswandi, M.Chiar with the results of the study that the School Committee had carried out its role as an advisory body, as a support agency, as a governing body, and as a mediator agent. ${ }^{4}$ The school committee must be able to convince parents, the local government, the business community, and the community at large that the school can be trusted. It was mentioned in a study that mentioned the relationship between principals, parents and homeroom teachers affects many things. ${ }^{5}$

The existence of school committee is not only in Indonesia, but also in other countries like Zimbabwe (Nyandoro et al., 2015, Wushe et al (2014) ${ }^{6}$, Nigeria (Ayeni and Olusola, 2013) ${ }^{7}$, Tanzania (Masue, 2013), (Nemes, 2013), Kenya (Xabu, 2015; Kiprono et al., 2015), and South Africa (Naidoo, 2013). The purpose, role, and school committee function at overseas emphasizes on empowerment of certain roles of school committee and the integration of parents in monitoring, assistance, and school finance management.

Based on previous studies, it is known that school committee has its own role, function, and responsibility to improve school performance. However, the reality showed that the implementation was still partial therefore it needs to be improved in order to be empowered. Therefore, the members of school committee need to be trained properly to increase their understanding about the basic concept of school committee, programming of school committee, and preparation of bylaws of school committee. In this case, the values of local

\footnotetext{
${ }^{4}$ Herwan Herwan, Aswandi Aswandi, and M. Chiar, "The Role of School Committee in Supporting The Fulfillment of Education Facilities and Infrastructure," JETL (Journal Of Education, Teaching and Learning) 3, no. 2 (2018): 282, doi:10.26737/jetl.v3i2.763.

${ }^{5}$ M. Novailul Abid, "Integrasi Nilai Islami Dalam Layanan Informasi Kesehatan Reproduksi," Kodifikasia 13, no. 2 (December 6, 2019): 251, doi:10.21154/kodifikasia.v13i2.1785.

${ }^{6}$ Tawaziwa Wushe and Jacob Shenje, “An Analysis of Basic Management and Financial Skills By School Development Committees ( Sdc ) in Selected Harare Schools" 1, no. 10 (2014): 378-86.

${ }^{7}$ Adeolu Joshua Ayeni and Williams Olusola Ibukun, “A Conceptual Model for School-Based Management Operation and Quality Assurance in Nigerian Secondary Schools," Journal of Education and Learning 2, no. 2 (2013): 36-43, doi:10.5539/jel.v2n2p36.
}

43 | At-Tarbiyat : Jurnal Pendidikan Islam, Vol. 03 No. 01 (2020) : 41-53 
wisdom as ancestral heritage used as intermediary and training tool in a shared life value system in a the form of religion, cultural, and customs (Priyanto, 2017).

The purpose of this research is to describe the performance of Minimum Standard of Education (MSE) in Junior High School in Jepara.

\section{Material and Method}

The subject of reseach was Junior High School in Jepara. The population of research was all members of school committee on Jepara which consisted of 91 State Junior High School and Private Junior High School. The sample was taken from 11 Juior High School with categories of eight (8) state Junior High School and three (3) private Junior High School. The design of research was qualitative descriptive. The data was collected in the form of document, material, time table, and activities notes of school committee supervision toward the performance of Minimum Standard of Education (MSE) of school in Jepara. The source of data was the administrator of school committee and principle of Junior High School. The technique of data collection used was through questionnaire, interview, documentation study, and observation.

The Result and Discussion of The Performance of Minimum Standard of Education in Junior High School in Jepara

Based on the research result on three (3) state Junior High School in Jepara district, four (4) state Junior High School in Jepara sub-district, and 3 (three) private Junior High School was gained data of Standard Minimal of Education (SME) Performance of Junior High School as shown in the following table 1 below:

Table 1 The Performance of Minimum Service Standard (MSS) of Education in Junior High School in Jepara district based on Minister of Education and

Culture Regulation Number 23 in 2013 


\begin{tabular}{|c|c|c|}
\hline \multirow[t]{2}{*}{ Type of Education Service } & \multicolumn{2}{|c|}{ Implementation Statement } \\
\hline & $\begin{array}{l}\text { State of } \\
\text { Junior High } \\
\text { School }\end{array}$ & Private Junior High School \\
\hline $\begin{array}{l}\text { The number of students in each study } \\
\text { group }\end{array}$ & $\begin{array}{l}\text { fulfilled } \\
100 \%\end{array}$ & unfulfilled $75 \%$ \\
\hline $\begin{array}{l}\text { Each Junior High School was provided } \\
\text { science laboratory }\end{array}$ & $\begin{array}{l}\text { fulfilled } \\
100 \%\end{array}$ & Unfulfilled $70 \%$ \\
\hline $\begin{array}{l}\text { One teacher room equipped table and } \\
\text { chair for each teacher, principle, and } \\
\text { education staff. }\end{array}$ & $\begin{array}{l}\text { fulfilled } \\
100 \%\end{array}$ & unfulfilled $75 \%$ \\
\hline $\begin{array}{l}1 \text { (one) teacher is available for } 32 \\
\text { students and } 6 \text { (six) teachers for each } \\
\text { education unit }\end{array}$ & $\begin{array}{l}\text { Fulfilled } \\
100 \%\end{array}$ & Fulfilled $75 \%$ \\
\hline $\begin{array}{l}1 \text { (one) teacher is available to each } \\
\text { subject }\end{array}$ & Fulfilled & Fulfilled $85 \%$ \\
\hline $\begin{array}{l}2 \text { (two) teachers qualified of s1 academic } \\
\text { and } 2 \text { (two) teachers had educator } \\
\text { certificate }\end{array}$ & $\begin{array}{l}\text { Fulfilled } \\
100 \%\end{array}$ & Fulfilled $83 \%$ \\
\hline $\begin{array}{l}\text { There were teachers with academic of S- } \\
1 \text { or D-IV of } 70 \% \text { and half of them ( } 35 \% \\
\text { of all teachers) had educator certificates }\end{array}$ & $\begin{array}{l}\text { Fulfilled } \\
100 \%\end{array}$ & Fulfilled $100 \%$ \\
\hline $\begin{array}{l}\text { There were teachers with academic } \\
\text { qualification of S-1 or D-IV had } \\
\text { educator certificates one for } \\
\text { Mathematics, Science, Indonesian, } \\
\text { English, and Civic Eduation }\end{array}$ & $\begin{array}{l}\text { Fulfilled } \\
100 \%\end{array}$ & Fulfilled $90 \%$ \\
\hline $\begin{array}{l}\text { All principles of Junior High School } \\
\text { were academic qualified of S- } 1 \text { or D-IV } \\
\text { and had educator certificate }\end{array}$ & $\begin{array}{l}\text { Fulfilled } \\
100 \%\end{array}$ & Fulfilled $100 \%$ \\
\hline $\begin{array}{l}\text { All school supervisors were academic } \\
\text { qualified of S-1 or D-IV and had } \\
\text { educator certificates }\end{array}$ & $\begin{array}{l}\text { Fulfilled } \\
100 \%\end{array}$ & $\begin{array}{l}\text { Fulfilled } \\
100 \%\end{array}$ \\
\hline $\begin{array}{l}\text { Principles supervised classrooms and } \\
\text { gave feedback to teachers twice in every } \\
\text { semester }\end{array}$ & $\begin{array}{l}\text { Fulfilled } \\
(74 \%)\end{array}$ & Fulfilled 55\% \\
\hline $\begin{array}{l}\text { Supervisor's visit to education unit was } \\
\text { once every month and every visit was } 3 \\
\text { hours long to conduct supervision and } \\
\text { guidance }\end{array}$ & $\begin{array}{l}\text { Fulfilled } \\
(75 \%)\end{array}$ & Fulfilled $66 \%$ \\
\hline
\end{tabular}

45 | At-Tarbiyat : Jurnal Pendidikan Islam, Vol. 03 No. 01 (2020) : 41-53 
Based on the research result of three (3) state of Junior High School in Jepara district, four (4) state of Junior High School in Jepara sub-district, and three (3) private Junior High School was gained data of implementation of school committee duties presented in table 2 .

Table 2 Performance of school committee in supervising of Minimum Standard Service (MSS) implementation in Junior High School Jepara Based on

Ministerial Regulation of Education and Culture number 75 in 2016

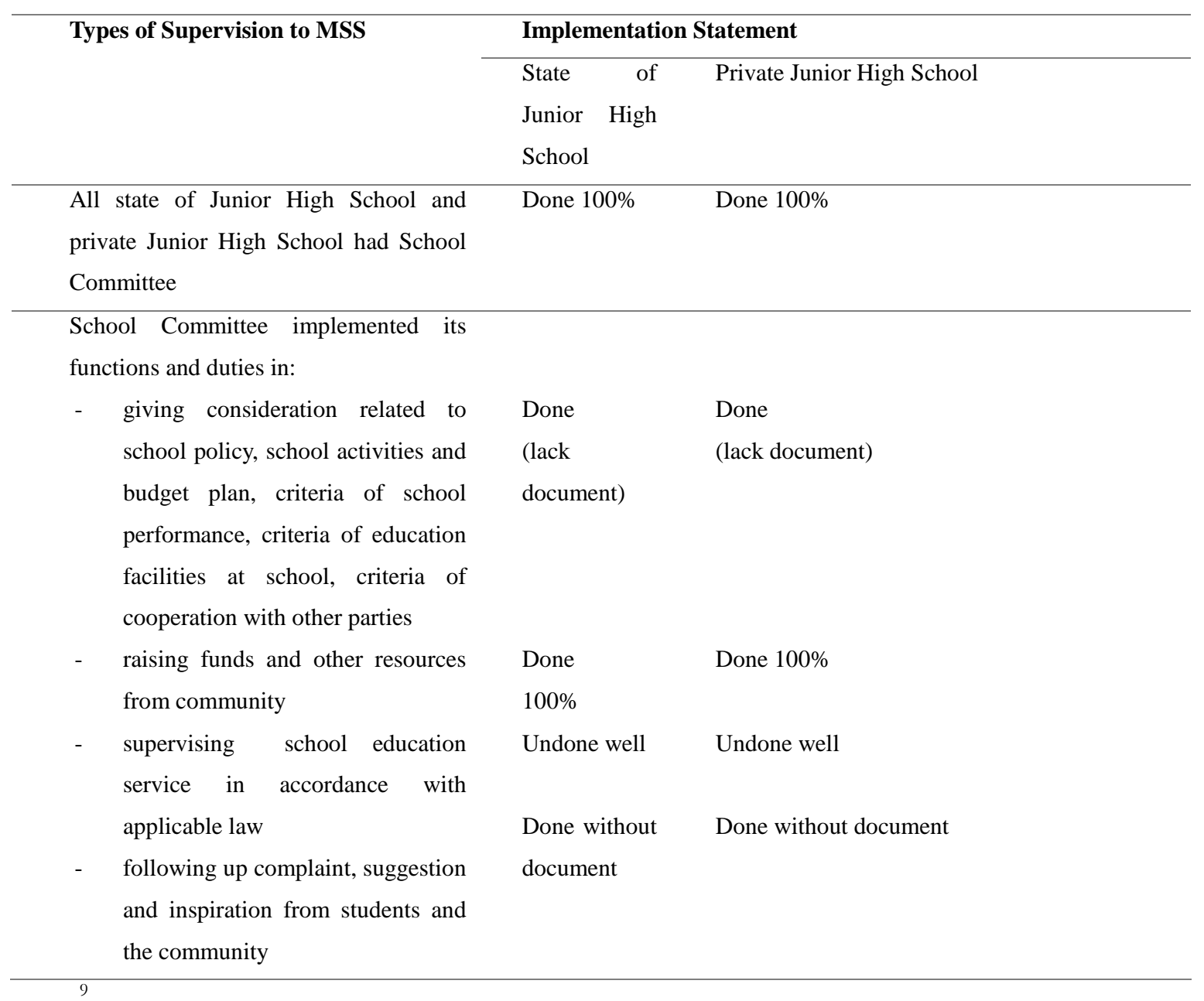

\footnotetext{
${ }^{8}$ Kemdikbud, "Peraturan Menteri Pendidikan Dan Kebudayaan Republik Indonesia Nomor 23
} Tahun 2013 Tentang Perubahan Atas Peraturan Menteri Pendidikan Nasional Nomor 15 Tahun 2010 Tentang Standar Pelayanan Minimal Pendidikan Dasar Di Kabupaten/Kota,” 2013, http://vervalsp.data.kemdikbud.go.id/prosespembelajaran/file/Permen Nomor 23 Tahun 2013.pdf.

${ }^{9}$ Depdiknas, "Peraturan Menteri Pendidikan Dan Kebudayaan Republik Indonesia Nomor 75.Tahun 2016 Tentang Komite Sekolah."

46 | At-Tarbiyat : Jurnal Pendidikan Islam, Vol. 03 No. 01 (2020) : 41-53 
Jordan's research (2005) in South Africa. This research focused on characteristics of participant, representation, and decision making of school mastery in South Africa based on collective case to six schools at Gauteng and Kwa-Zulu Natal (KZN) taken over between 2002 and 2004. ${ }^{10}$ This research was located in six school at Gauteng and Kwa-Zulu Natal (KZN) in South Africa. The research result showed the existence of School Governing Body (SGB), at least, has opened space of participatory democracy. There were variations in the development of various types of schools that have been previously set policy officially and stakeholder involvement at school. Participation space reflected bias of managerial and institutional action logic emphasized that authority (real or unreal) was focused on achievement of school interests.

In addition, Fanny (2006) with her research concluded that improving the context of education and training which was relevant for participants and work units has a positive and significant contribution, namely improving work skills, knowledge, attitudes, and education and training skills of participants.

Nemes'research (2013) showed that majority of state of elementary school had WSDPs functionally. The implication was aspiration about PEDP I to give training to school committee related to WSDPs has been spread according to the rules. Even this research showed school committee actively involved in preparation, monitoring implementation, and evaluation of WSDPs. ${ }^{11}$

Masue (2013) conducted research for dessertation in Tanzania. The focus of this research is schoolcommittee empowerment and parents in school management specifically in subsector of basic education in Tanzania. ${ }^{12}$ The purpose of this research was: (1) to describe empowerment of school committee and parent; (2) to identify factors that influence school committee empowerement in Tanzania; (3) to deliver policy to improve empowerment of lower class people in school management. The research location was at 101 schools in district or sub-

\footnotetext{
${ }^{10}$ Naidoo.J.P., "Educational Decentralization and School Governance in South Africa:," 2005, http://www.unesco.org/iiep.

${ }^{11}$ Joyce Nemes, "School Committees in the Context of Preparing and Implementing Whole School Development Planning" 4 (January 1, 2013): 2013.

${ }^{12}$ Orest Sebastian Masue, "Empowerment and Effectiveness of School Committees in Tanzania," Access, 2010.
}

47 | At-Tarbiyat : Jurnal Pendidikan Islam, Vol. 03 No. 01 (2020) : 41-53 
district of Tanzania. The result research showed that: (1) trend was found in the form of three levels of empowerment, namely DEO (index of 42), DUO (index of 39), and DOI (index of 37). This research gained phenomena of Dalam penelitian ini didapatkan fenomena of empowerment acceptance which has decreased throughout the unity of DEO to DOI Gender, as access to obtain information and become a member of a school committee was significant in determining not only for school committee members but also generally for parents.

Hafiz (2013) conducted research in Lahore Pakistan. The research result showed that school and family must routinely utilize community resources to educate children. In fact, community representatives and resources can be directed at each of five types of involvement, they are: communication with family, volunteer, learning advocate, and school committee participation. Thus, it can be concluded that there was significant relationship between two variables, namely the level of parental involvement in student academic activity and the level of children's achievement. ${ }^{13}$

Chris Robbins and Linda Searby (2013) conducted research entitled “Exploring Parental Involvement Strategies Utilized by Middle School Interdisciplinary Teams." The focus of research was the strategy of parental involvement seconded in interdisciplinary teaching teams from three different secondary schools, namely advanced schools from urban areas, standard schools in rural areas, and the poorest urban schools. The findings of research were as a bridge to adolescent development, interdisciplinary team models in secondary schools, and the main characteristics of parental involvement in education.

Olusola's research journal (2013) is entitled "A Conceptual Model for SchoolBased Management Operation and Quality Assurance in Negarian Secondary Schools". It focused on the involvement of the School Based Management Committee (SBMC) and the effectiveness in school settings, curriculum implementation, and student learning outcomes in high schools in Nigeria. The research was located in high school in Nigeria. The research finding showed that

\footnotetext{
${ }^{13}$ Hafiz Muhammad et al., "Parental Involvement and Academic Achievement; A Study on Secondary School Students of Lahore , Pakistan," Parental Involvement and Academic Achievement ; A Study on Secondary School Students of Lahore, Pakistan 3, no. 8 (2013): 209-23.
}

48 | At-Tarbiyat : Jurnal Pendidikan Islam, Vol. 03 No. 01 (2020) : 41-53 
model concept unconnected was adopted to empower operational capacity of School Based Management Committee to serve efficiently with quality of learning outcomes in high schools. The main challenge in conducting SBMC operationally and effectively was identified based on some points namely low capacity by prominent member from SBMCs, lack of attendance of SBMCs members due to lack of incentives and financial support from government, and lack of cooperation from schools as well. These results met ineffectiveness of school management and low student academic achievement. From the journal mentioned above, it was known that the previous model of school committee empowerment training management only emphasized to the empowerment of school committee in the implementation of school based management.

Furthermore, Nyandoro et al (2015) conducted this research in primary schools at West Circuit at Chimanimani, Province of Maniculand, Zimbabwe. The research findings showed that School Development Committees are not effective in managing their school finance because they were lack of professionals in various aspects of finance management like preparation and budget's utilization to determine decision, to maintain an inventory of school assets, and to increase fundings. ${ }^{14}$

Kiprono et al (2015) conducted research at Kenya. This research focused on school management by emphasizing the collection of funds and learning resources in schools. ${ }^{15}$ This research was located in District of East Eldorest, Kenya. The research finding showed that the majority of respondents taken did not have ability to implement free basic education fund in school management committee. In the other hand, in the meantime, they were lack of calculation ability and lack of ongoing personality development and training as well.

\footnotetext{
${ }^{14}$ Joyce Nyandoro, John Mapfumo, and Richard Makoni, "Effectiveness of School Development Committees in Financial Management in Chimanimani West Circuit Primary Schools in Zimbabwe," Academic Research International 4, no. 1 (2013): 255-74.

${ }^{15}$ Faith J Kiprono, Mary Nganga, and Joyce Kanyiri, “An Assessment of School Management Committees' Capacity in the Implementation of Fpe Funds in Public Primary Schools: A Survey of Eldoret East District, Kenya," International Journal of Education and Research 3, no. 3 (2015): 243-60, www.ijern.com.
}

49 | At-Tarbiyat : Jurnal Pendidikan Islam, Vol. 03 No. 01 (2020) : 41-53 
Journalarticles discussed above can be concluded that:

1. Education management in all countries always involved parents and society.

2. Parents and community were a part of committee.

3. The involvement of parents and community started from planning, implementation, supervision, and assessment.

4. Committee empowerment was conducted through training.

5. The existence of school committee in Indonesia had the same function and duty as other countries in the world.

School Committee performance at Junior high School in Jepara has not implemented well due to three reasons, namely (1) there were no technical instructions about school committee performance, (2) there were no training of School Committee except the material taken based on school committee needs, (3) the rush hour of school committee.

\section{Conclusion}

The implementation result of Minimum Standard of Education (MSE) of Junior High School can be concluded that: (1) All state of Junior High School as well as Private Junior High Schol has conducted MSE in accordance with recommendation of the Minister of Education and Culture Number 23 in 2013; (2) The MSE of Private Junior High Schools were unfulfilled on the same indicator, especially laboratory; (3) Not all teachers were teaching in accordance with Lesson Plan, in other words, Lesson Plan was only for administrative documents; (4) The implementation to supervise was unfulfilled; and (5) Class supervisory to Principle has not implemented well. The implementation of school committee performance of MSE in Junior High School in Jepara has been conducted $80 \%$. It is meant that MSE in Junior High School has not fulfilled yet. In other words, the performance of school committee in supervising MSE in Junior High School Jepara was good. 


\section{SUGGESTION}

The Government and Regional Government should issue decree about the function and the task of school committee. Besides, the Education Authority and Education Board should hold the training of school committee which meets a need. 


\section{REFERENCES}

Abid, M. Novailul. "Integrasi Nilai Islami Dalam Layanan Informasi Kesehatan Reproduksi." Kodifikasia 13, no. 2 (December 6, 2019): 251. doi:10.21154/kodifikasia.v13i2.1785.

Ayeni, Adeolu Joshua, and Williams Olusola Ibukun. "A Conceptual Model for School-Based Management Operation and Quality Assurance in Nigerian Secondary Schools." Journal of Education and Learning 2, no. 2 (2013): 3643. doi:10.5539/jel.v2n2p36.

Curry, Katherine, Sean Kinder, Tania Benoiton, and Jessica Noonan. "School Board Governance in Changing Times: A School's Transition to Policy Governance." Administrative Issues Journal: Education, Practice, and Research 8, no. 1 (2018): 1-17. doi:10.5929/2018.8.1.1.

Depdiknas. "Peraturan Menteri Pendidikan Dan Kebudayaan Republik Indonesia Nomor 75.Tahun 2016 Tentang Komite Sekolah." Permendikbud Nomor 75 Tahun 2016, 2016, 1-11.

Halik, Abdul, S. Wardah Hanafie Das, Muhammad Aswad, M. Syakir Rady, Muhammad Siri Dangnga, and M. S. Nasir. "Empowerment of School Committee in Improving Education Service Quality at Public Primary School in Parepare City." Universal Journal of Educational Research 7, no. 9 (2019): 1956-63. doi:10.13189/ujer.2019.070915.

Herwan, Herwan, Aswandi Aswandi, and M. Chiar. "The Role of School Committee in Supporting The Fulfillment of Education Facilities and Infrastructure." JETL (Journal Of Education, Teaching and Learning) 3, no. 2 (2018): 282. doi:10.26737/jetl.v3i2.763.

Kemdikbud. "Peraturan Menteri Pendidikan Dan Kebudayaan Republik Indonesia Nomor 23 Tahun 2013 Tentang Perubahan Atas Peraturan Menteri Pendidikan Nasional Nomor 15 Tahun 2010 Tentang Standar Pelayanan Minimal Pendidikan Dasar Di Kabupaten/Kota," 2013. http://vervalsp.data.kemdikbud.go.id/prosespembelajaran/file/Permen Nomor 23 Tahun 2013.pdf.

Kiprono, Faith J, Mary Nganga, and Joyce Kanyiri. "An Assessment of School Management Committees' Capacity in the Implementation of Fpe Funds in Public Primary Schools: A Survey of Eldoret East District, Kenya." International Journal of Education and Research 3, no. 3 (2015): 243-60. www.ijern.com. 
Masue, Orest Sebastian. "Empowerment and Effectiveness of School Committees in Tanzania." Access, 2010.

Muhammad, Hafiz, Waqas Rafiq, Malik Muhammad Sohail, and Muhammad Saleem. "Parental Involvement and Academic Achievement ; A Study on Secondary School Students of Lahore , Pakistan." Parental Involvement and Academic Achievement ; A Study on Secondary School Students of Lahore , Pakistan 3, no. 8 (2013): 209-23.

Naidoo.J.P. "Educational Decentralization and School Governance in South Africa:," 2005. http://www.unesco.org/iiep.

Nemes, Joyce. "School Committees in the Context of Preparing and Implementing Whole School Development Planning" 4 (January 1, 2013): 2013.

Nyandoro, Joyce, John Mapfumo, and Richard Makoni. “Effectiveness of School Development Committees in Financial Management in Chimanimani West Circuit Primary Schools in Zimbabwe." Academic Research International 4, no. 1 (2013): 255-74.

Wushe, Tawaziwa, and Jacob Shenje. "An Analysis of Basic Management and Financial Skills By School Development Committees ( Sdc) in Selected Harare Schools" 1, no. 10 (2014): 378-86. 